\title{
IMPLEMENTASI TOTAL QUALITY MANAGEMENT (TQM) DALAM LEMBAGA PENDIDIKAN BERBASIS PESANTREN
}

Nailatul Mahmudah

Universitas Nurul Jadid

Manajemen Pendidikan Islam

Email: naila.mahmudah6@gmail.com

\begin{abstract}
ABSTRAK
Pentingnya peningkatkan mutu lembaga pendidikan, tidak bisa terlepas dari upaya perbaikan manajemennya. Komponen yang terpenting dalam pendidikan yaitu bagaimana manajemen pondok pesantrennya, sekolahnya maupun madrasahnya yang perlu untuk adanya perbaikan. Oleh karena itu, Pendidikan pondok pesantren yang berkualitas tidak hanya ditentukan dengan adanya guru, tetapi juga dipengaruhi oleh seluruh personil dan pendidikan elemen, seperti : siswa, manajemen administrasi, kurikulum, visi, dan misi. Ada kemungkinan untuk mengaplikasikan teori manajemen dalam proses penyelenggaraan pembelajaran di sekolah dan madrasah yang berbasis pesantren supaya lembaga pendidikan bisa menghasilkan lulusan yang berkualitas yang sesuai dengan tuntutan zaman pada saat ini. Oleh karenanya, Total Quality Management tidak hanya diposisikan sebagai strategi dan pendekatan dalam memajukan pendidikan yang berkualitas, tetapi juga diposisikan sebagai sistem integral peningkatan kualitas di pendidikan dan cara hidup dalam mencapai tujuan yang efektif dan efisien. Implementasi TQM di lembaga pendidikan yang berbasis pesantren harus dilaksanakan sebagai upaya dalam meningkatkan kualitas pendidikan yang memiliki daya saing tinggi. Strategi ini harus dilakukan terus menerus untuk mengoptimalkan kualitas dan produktivitas pendidikan yang berbasis pesantren dengan berpegang teguh pada prinsip agama yang mana harus terus menerus adanya perbaikan.
\end{abstract}

Kata Kunci : manajemen, pendidikan, pesantren, TQM. 


\section{A. Pendahuluan}

Pesantren telah berdiri sejak abad ke-15 sebagai warisan dari para ulama yang tidak pernah luntur karena kuatnya system pendidikan baik dari pengajaran klasik atau modern yang diberikan oleh pesantren. Pesantren adalah sebuah lembaga pendidikan Islam yang terdiri dari nilai-nilai agama dan transformasi budaya yang berada di sekitar masyarakat. Sehingga, dengan inilah yang menjadikan pesantren masih tetap ada hingga saat ini. pesantren juga mempunyai khas tersendiri dalam gaya kepemimpinannya yang membedakan dari lembaga lainnya, yaitu dengan cara penerus kepemimpinan pondok pesantren akan dipimpin oleh para generasi penerus dari pondok pesantren sendiri. Pesantren dapat dikatakan bermutu ${ }^{1}$ jika dapat menghasilkan output yang dapat menyatukan antara pendidikan agama dan umum selain itu juga dapat bersosialisasi baik dengan masyarakatnya.

Mutu pendidikan adalah suatu proses yang sangat berhubungan dengan proses peningkatan kualitas SDM yang ada dan juga manajemen yang terdapat didalam lembaga pendidikan itu sendiri. Jadi, mengingat pentingnya proses peningkatan kualitas SDM dan juga manajemen yang terdapat didalamnya, maka pemerintah bersama kalangan swasta sama-sama telah berupaya dalam mewujudkan amanah tersebut melalui berbagai usaha yang telah dilalui. ${ }^{2}$

Dalam kamus Ilmiah popular mutu bisa dikatakan sebagai kualitas, derajat, dan tingkat. Dan dalam bahasa Inggris, mutu berasal dari kata Quality yang mempunyai arti kualitas. ${ }^{3}$ Secara umum, mutu mempunyai makna derajat (tingkat) keunggulan suatu produk (sebuah hasil kerja) baik berupa barang maupun jasa. Sedangkan Goetsch dan Davis dalam buku Total Quality Management, mengartikan bahwa kualitas mempunyai arti suatu kondisi dinamis yang berhubungan dengan produk, proses, manusia, jasa, dan lingkungan yang memenuhi harapan yang ingin dicapai. ${ }^{4}$

1 mutu dapat diartikan sebagai kemampuan pesantren dalam pengelolaan secara operasional dan efisien terhadap komponen-komponen yang berkaitan dengan pesantren sehingga menghasilkan nilai tambah terhadap komponen tersebut menurut norma/standar yang berlaku. Mukhamad Ilyasin \& Nanik Nurhayati, Manajemen Pendidikan Islam, (Yogyakarta: Aditya Media, 2012), p. 261.

${ }^{2}$ Umaedi, Manajemen Peningkatan Mutu, Dalam Http:// Ssep.Net /Director. Html. Diakses Pada Tanggal 10 Mei 2018.

${ }^{3}$ Pius A. Partanto, Kamus Ilmiah Populer (Surabaya: Arkola, 1994), hlm. 505.

${ }^{4}$ Fandy Tjiptono Dan Anstasia Dian, Total Quality Manajemen (Yogyakarta: Andi, 2001), hlm. 4. 
Jadi dapat disimpulkan bahwa mutu/kualitas merupakan suatu proses pengelolaan/usaha yang telah dicapai dalam suatu organisasi/lembaga tersebut. Yang mana mutu/kualitas ini menjadi sasaran utamanya.

TQM (Total Quality Management) atau yang kita kenal dengan Manajemen Mutu Terpadu adalah konsep manajemen pendidikan yang diambil dari konsep manajemen industry yang kemudian dianggap penting dan diimplementasikan kedalam dunia pendidikan. Total quality management berarti suatu konsep manajemen dengan totalitas penekanannya yang bertumpu pada mutu / kualitas yang mana kualitas ini sangat menunjang terhadap suatu lembaga pendidikan itu sendiri. Dalam hal ini, qualitas sangat diutamakan dan juga harus disertai dengan adanya perbaikan yang terus menerus demi terciptanya kualitas yang optimal. ${ }^{5}$

Edward Sallis mengemukakan bahwa "Total Quality Management is a philosophy and a methodologhy wich assist institutions to manage change and set their own agendas for dealing with the plethora of new external pressures." (Manajemen mutu terpadu merupakan filsafat dan metodologi yang mana membantu institusi-institusi, untuk mengelola perubahan dan menyusun agendaagenda untuk menanggapi tekanan faktor eksternal yang berlebihan). ${ }^{6}$

Jadi dapat disimpulkan bahwa menejemen mutu terpadu yaitu suatu metode untuk membatu menyusun suatu agenda demi tercapainya suatu tujuan. Dan dalam hal ini kualitas/mutu suatu organisasi sangat diprioritaskan dan dalam mencapai mutu/kualitas ini maka kuncinya harus disertai dengan kepuasan para pelanggan.

\section{B. PENERAPAN TQM DALAM LEMBAGA BERBASIS PESATREN}

TQM merupakan suatu system yang sangat efektif untuk menggabungkan usaha- usaha pengembangan, pemeliharaan, dan perbaikan kualitas atau mutu berbagai kelompok dalam suatu organisasi. Sehingga, dapat meningkatkan produktivitas dan pelayanan ketingkat yang paling ekonomis dan menimbulkan kepuasan semua pelanggan. Jadi, TQM disini yaitu suatu system yang mana system ini dapat membantu dalam menggabungkan berbagai usaha pngembangan,

5 S. Soimatul Ula, Buku Pintar Teori-Teori Manajemen Pendidikan Efektif (Yogyakarta: Berlian, 2013), hlm. 40.

${ }^{6}$ Edward Sallis, Total Quality Management In Education, Terj. Ahmad Ali Riyadi, Cet. Ke4(Yogyakarta: Ircisod, 2011), hlm. 33. Lihat Juga Dalam Agus Fahmi, Dkk, Konsep Pendidikan.... hlm. 68. 
pemeliharaan dan lain sebagainya yang menyangkut dengan penunjang berkualitasnya suatu organisasi atau lembaga.

Total Quality Management (Manajemen Mutu Terpadu) adalah suatu pendekatan manajemen yang menfokuskan terhadap peningkatan mutu produk yang dihasilkan oleh suatu lembaga / organisasi untuk kepuasan pelanggan. Demi meningkatkan mutu/kualitas produk yang akan dihasilkan dari sebuah lembaga itu sendiri maka harus diikuti dengan adanya perbaikan-perbaikan yang terus menerus dilakukan oleh lembaga organisasi tersebut. Perbaikan-perbaikan itu bisa dimulai dari proses perbaikan mutu/kualitas, dengan hal itu maka TQM diharapkan bisa mengurangi peluang terjadinya sebuah kesalahan dalam menghasilkan produk, karena produk yang baik adalah harapan para pelanggan. Rancangan produk yang akan dihasilkan juga akan diproses sesuai dengan prosedur dan teknik untuk mencapai harapan pelanggan.

Dalam penerapan TQM ini saya mengambil contoh dari lembaga pendidikan yang berada didalam naungan pondok pesantren Tanjung Rejo Situbondo.

\section{Objek}

Dalam suatu penerapan, pasti harus disertai dengan adanya suatu objek yang mana objek ini yang akan menunjang atas keberhasilan suatu lembaga/organisasi. Penerapan tanpa adanya objek tidak akan sukses/berjalan konsep yang telah kita buat sebelumnya, sebaliknya ada objek akan tetapi tidak ada penerapan maka tidak akan berhasil konsep yang telah dibuat tersebut.

Dalam hal ini, yang menjadi objek dalam penerapan TQM yaitu para santriwan dan santriwati dan juga para pendidik (ustadz ustadzah). Santriwan santriwati dan juga para pendidik ini berada dibawah naungan pondok pesantren itu sendiri yang mana mereka semua itu dilatih dan diasah didalam pondok pesantren ini demi terciptanya out put yang berkualitas. Dengan adanya santriwan santriwati yang cerdas dan juga berakhlaqul karimah, maka dapat menunjang terhadap peningkatan kualitas manjemen dalam pendidikan pondok pesantren itu sendiri.

Santriwan santriwati ini sangat berperan penting dalam hal meningkatkan kualitas suatu lembaga pondok pesantren itu sendiri. Yang mana dalam hal ini para santriwan santriwati merupakan objek dalam penerapan TQM di lembaga pendidikan yang ada dalam naungan pondok pesantren ini. 


\section{Kegiatan santriwan santriwati didalam pondok pesantren}

Dalam meningkatkan mutu pendidikan pondok pesantren, santriwan santriwati dituntut untuk melakukan kegiatan berikut ini:

a) Berjamaah solat 5 waktu

Dalam pondok pesantren Tanjung Rejo ini santriwan santriwati diwajibkan untuk melakukan kegiatan berjamaah solat 5 waktu. jika terdapat salah seorang santriwan santriwati yang tidak melaksanakan solat berjamaah ini, maka pihak dari pengurus pesantren akan memberikan takzir/sanksi terhadap santriwan santriwati tersebut. Takzir itu sangat beragam tergantung dari para pengurus/ustadz/ustadzah yang menangani.

b) Mengaji Al-Qur'an

Dalam melaksanakan kegiatan mengaji ini, para santriwan santriwati di bimbing untuk mengaji dengan benar dan fasih. Adapun pembimbing atau guru ngajinya yakni Bu Nyai dan Pak Kyai yang menjadi pegasuh daripada pondok pesantren itu sendiri.

Bagi santriwan santriwati yang tidak mengikuti kegiatan ini maka $\mathrm{Bu}$ Nyai dan Pak Kyai sendiri yang akan memberikan takziran/sanksi tersebut. Mengaji Al-Qur'an disini biasanya dilakukan pada selesai/sehabis solat maghrib-isya' dan sehabis solat subuh (penyetoran hafalan juz 'amma, apabila sudah selesai dilanjutkan kepada juz 1 dan seterusnya).

c) Musyawaroh/diskusi

Musyawaroh disini biasanya dilakukan ba'da Isya' atau pada jam 08.00-10.00 setelah kegiatan berjamaah dan mengaji selesai. Pada kegiatan musyawaroh ini, para santriwan santriwati berdiskusi tentang pembelajaran yang akan dipelajari besok harinya (pelajaran diniyah maupun formalnya). Bagi santriwan santriwati yang tidak mengerti/tidak faham dapat bertanya langsung kepada ustadz/ustadzah yang mendampinginya.

d) Tahajjud/Dhuha

Selain wajib mengerjakan solat 5 waktu berjamaah, santriwan santriwati juga diwajibkan untuk mengerjakan solat tahajjud dan dluha. Solat Tahajjud itu sendiri, biasanya dilaksanakan pada malam hari atau 
sekitar jam 1.30-2.00 yang selanjutnya dilanjutkan dengan pembacaan asmaul husna. Sedangkan solat dluha ini dilakukan pada jam 06.30 yaitu pada jam dimana para santri sudah siap / masih bersiap-siap untuk pergi ke sekolah masing-masing.

e) Sekolah (formal maupun diniyah)

Dalam pondok pesantren santriwan santriwati biasanya tidak hanya dituntut untuk mempelajari ilmu pendidikan agama saja, akan tetapi para santri juga dituntut untuk mempelajari ilmu umum seperti Matematika, bahasa Indonesia, bahasa inggris dan lain sebagainya. Akan tetapi didalam pondok pesantren ini, para santri sama-sama ditekankan antara ilmu agama maupun ilmu umum. Itu semua dilakukan demi mencapai lulusan (out put) yang berkualitas dan bermanfaat bagi masa depan.

\section{Metode pembelajaran dalam pondok pesantren}

a) Sorogan yaitu suatu system belajar dimana para santri melakukan pembelajaran dengan cara berhadapan langsung dengan sang Kyai. Dengan metode ini sang Kyai dapat mengenal langsung satu persatu para santri. (biasanya santri putra yang akan dibimbing langsung oleh sang Kyai).

b) Bandungan yaitu bisa disebut juga dengan halaqoh, dalam pengajaran ini sang Kyai membaca kitab dan hanya satu kitab saja yang dibaca sedangkan para santri membawa kitab yang sama dan mendengarkan dan menyimak bacaan sang Kyai. (sang Kyai duduk di depan sedangkan para santri menyimak dan mendengarkan sang Kyai).

c) Weton yaitu pengajian yang hanya dilakukan pada saat- saat tertentu saja. Biasanya pengajian ini, pengajian yang hanya dilakukan pada saat bulan Ramadhan tiba yaitu santriwan santriwati akan diisi dengan kegiatan pengajian kitab selama bulan ramadhan. Kitabnya pun bukan kitab yang biasanya para santri kaji setiap harinya, akan tetapi kitab yang dikaji pada bulan Ramadhan ini langsung sang Kyai yang memilihnya. ('Ushfuriyah, fathul majid, nashoihul 'ibad, tanwirul qulub, dan lain sebagainya). 
Sedangkan metode yang dapat dilakukan dilingkungan pondok pesantren yaitu :metode Tanya jawab, diskusi, imla', muthola'ah, dialog, hafalan, dan lain sebagainya.

Dalam hal meningkatkan kualitas pendidikan pesantren, pesantren dapat menerapkan beberapa prinsip yang ada dalam TQM antara lain:

a) Focus terhadap pelanggan.

Dalam konsep ini, suatu kualitas tidak hanya bermakna kesesuaian dengan spesifikasi tertentu. Akan tetapi, kualitas suatu pendidikan itu dapat ditentukan dari kepuasan para pelanggan itu sendiri. Dengan terpenuhinya kebutuhan para pelanggan ini, maka akan semakin merasa puas pula para pelanggan tersebut.

Karena pendidikan merupakan pelayanan jasa dan Oleh karena itu, sekolah harus memberikan pelayanan jasa yang terbaik kepada pelanggannya. ${ }^{7}$ Yang dimaksud dengan pelanggan sekolah disini, yaitu pelanggan internal dan pelanggan eksternal. Pelanggan eksternal sekolah meliputi orang tua siswa, pemerintah, masyarakat, dan juga termasuk komite sekolah. Pelanggan internal sekolah meliputi siswa, guru dan staf tata usaha. Bisa disebut juga bahwa sekolah mempunyai pelanggan primer, sekunder dan tersier. Pelanggan primer sekolah meliputi siswa sedangkan pelanggan sekunder sekolah meliputi orang tua siswa sedangkan pelanggan tersier sekolah meliputi pemerintah dan masyarakat.

Jadi dapat disimpulkan bahwa dengan terpenuhinya kebutuhan siswa, orang tua siswa(wali murid), masyarakat, guru dan juga staf tata usaha maka akan lebih cepat juga untuk menuju lembaga yang berkualitas/ bermutu.

Adapun beberapa penerapan khusus bagi orientasi pelanggan yaitu :

1) teliti, pahami kebutuhan dan harapan pelanggan.

2) pastikan bahwa sasaran organisasi sejalan dengan kebutuhan dan harapan pelanggan.

\footnotetext{
${ }^{7}$ Husaini Usman, Manajemen Teori, Praktik, Dan Riset Pendidikan, (Jakarta: Bumi Aksara,
} 2006), hlm. 464. 
3) komunikasikan kebutuhan dan harapan pelanggan ke seluruh organisasi.

4) ukur kepuasan pelanggan lalu ambil tindakan dari hasil pengukuran.

5) buatlah keseimbangan pendekatan antara kepuasan pelanggan dan pihak-pihak yang berkepentingan lainnya, seperti: pemilik modal/kepala sekolah, karyawan/guru, masyarakat dan pemerintah.

Jadi sebelum melakukan suatu tindakan kita harus melakukan survey atau bisa dengan menyebarkan angket kebutuhan para pelanggan terlebih dahulu, dengan demikian maka kita akan tahu apa yang dibutuhkan para pelanggan.

Seperti yang telah disebutkan diatas kita harus megetahui kebutuhan apa yang dibutuhkan para pelanggan. Karena jika jika tindakan yang kita ambil tidak sejalan dengan kebutuhan para pelanggan maka tidak akan terjadi kepuasan para pelanggan dan jika pelanggan tidak puas maka akan sulit bagi suatu organisasi/lembaga untuk menjadi lembaga yang berkualitas/bermutu. Karena kunci dari lembaga/oranisasi yang bermutu yaitu kepuasan dari para pelanggan itu sendiri.

\section{b) Optimalisasi peran kepemimipan}

Seorang pemimpin harus mampu menentukan kesatuan arah dan tujuan organisasi. Pemimpin juga harus menjaga dan menciptakan / memelihara lingkungan eksternal dimana orang-orang dapat terlibat dengan penuh dalam pencapaian tujuan organisasi.

Dalam hal ini, seorang kepala sekolah dituntut untuk menjadi penasehat sekaligus motor penggerak bagi bawahannya dalam upaya perbaikan. Oleh karena itu, kepala sekolah harus memahami tujuan, prinsip, dan juga elemen pendukung TQM. Kepala sekolah juga dituntut untuk mampu mengolanya secara terus menerus demi peningkatan kualitas lembaga pendidikan tersebut. ${ }^{8}$

\footnotetext{
${ }^{8}$ S. Soimatul Ula, Buku Pintar..., lm. 48.
} 
c) Perbaikan berkesinambungan

Agar dapat sukses setiap lembaga pendidikan/organisasi perlu melakukan adanya perbaikan-perbaikan secara berkesinambungan. Usaha ini harus dilakukan dengan terus menerus, yaitu dengan melakukan perbaikan dan perbaikan. Konsep yang digunakan yaitu siklus PDCAA (plan, do, check, action, analyze), yang terdiri dari langkah-langkah perencanaan, dan melakukan tindakan korektif terhadap hasil yang diperoleh. ${ }^{9}$

Beberapa penerapan khusus untuk perbaikan secara berkelanjutan, antara lain :

1) laksanakan secara konsisten pendekatan organisasi untuk kontinuitas (kelangsungan) perbaikan performasi.

2) sediakan dan kirim SDM untuk pelatihan terhadap metode dan alat perbaikan berkesinambungan.

3) laksanakan perbaikan yang kontinu pada produk, proses dan sasaran system.

4) tetapkan tujuan dan sasaran sebagai pedoman, ukur pencapaian untuk perbaikan yang berkesinambungan.

5) beri penghargaan dan pengakuan terhadap perbaikan.

d) Respek terhadap setiap orang.

Ada beberapa penerapan khusus untuk respek terhadap setiap orang, antara lain :

1) Mengupayakan setiap orang agar memahami pentingnya konstribusi dan peran mereka dalam organisasi.

2) Mengupayakan setiap orang agar mengenali batasan kinerja serta tanggung jawab mereka dalam organisasi.

3) Mengupayakan setiap orang agar mengetahui permasalahan kerja mereka dan juga termotivasi untuk menyelesaikannya.

4) Mengajak setiap orang aktif melihat peluang untuk meningkatkan kompetensi, pengetahuan dan pengalaman mereka.

\footnotetext{
${ }^{9}$ Husaini Usman, Manajemen ...., hlm. 464.
} 
5) Memfasilitasi agar setiap orang bebas berbagi pengetahuan / pengalaman dan juga berinovasi.

6) Membudayakan agar setiap orang secara terbuka mendiskusikan permasalahan yang ada agar segera terselesaikan.

e) Manajemen berdasarkan fakta

Dalam pengambilan keputusan harus selalu didasarkan pada data bukan sekedar pada perasaan (feeling), dalam hal ini pemimpin harus bersikap bijaksana dalam mengambil keputusan dan tidak memihak kepada salah satu bawahannya. Ada 2 konsep pokok yang berkaitan dengan hal ini, yaitu : (1). Prioritas (prioritization), yaitu konsep yang menjelaskan bahwa perbaikan tidak dapat dilakukan pada semua aspek pada saat yang bersamaan karena keterbatasan sumber daya yang ada. Yang dimaksud disini yaitu bahwa dalam melakukan perbaikan kita tidak bisa melakukannya secara bersamaan, melainkan kita harus melakukannya satu persatu dan bertahap. Karena dalam melakukan suatu hal manusia mempunyai keterbatasan manusia tidak bisa melakukan semua hal secara bersamaan, manusia mempunyai kapasitas yang sangat terbatas. (2). Variasi / variabilitas kinerja manusia. ${ }^{10}$

Ada beberapa penerapan khusus bagi manajemen berdasarkan fakta, antara lain :

1) pastikan bahwa data dan informasi cukup akurat dan dapat dipercaya.

2) sediakan data yang diakses oleh yang membutuhkan.

3) analisa data dan informasi dengan menggunakan metode yang valid.

4) buat keputusan dan ambil tindakan berdasarkan analisis faktual, seimbang dengan pengalaman intuisi.

Intinya dalam penerapan ini kita dianjurkan untuk melakukan sesuatu berdasarkan fakta yang ada (real) bukan atas sesuatu yang mengada-ada (fake). 
Ada beberapa komponen TQM yang harus diperhatikan dalam penerapan TQM ini, diantaranya: ${ }^{11}$
a) Focus pada pelanggan.
b) Obsesi terhadap kualitas.
c) Pendekatan ilmiah.
d) Komitmen jangka panjang.
e) Kerja sama tim.
f) Perbaikan system secara berkesinambungan.
g) Pendidikan dan pelatihan.
h) Kebebasan yang terkendali.
i) Kesatuan tujuan.
j) Adanya keterlibatan dan pemberdayaan karyawan.

\section{ANALISA PENERAPAN TQM DALAM LEMBAGA PENDIDIKAN BERBASIS PESANTREN}

Dipandang dari konsep manajemen, dalam manajemen pesantren sudah seharusnya memandang bahwa proses Pendidikan yang dilakukan oleh santriwan santriwati adalah suatu peningkatan terus menerus yang dimulai dari sederet siklus sejak adanya ide-ide untuk menghasilkan lulusan (output) yang berkualitas.

Oleh karena itu, dalam jangka panjang manfaat dari implementasi TQM di lembaga pendidikan yang bernaungan pondok pesantren diantaranya yaitu perbaikan pelayanan, pengurangan biaya, dan juga kepuasan para santri dan juga wali santri. Perbaikan yang progresif dalam menjalankan system manajemen dan kualitas pelayanan dapat menghasilkan dalam peningkatan kepuasan pelanggan. Disisi lain manfaat yang dapat diambil yaitu peningkatan keahlian, semangat dan rasa percaya diri dikalangan guru dan staf adminitrasi, perbaikan hubunga antara internal ponpes dan masyarakat, peningkatan akuntabilitas, transparansi peningkatan produktifitas dan efesiensi.

Adapun contoh penerapan TQM di lembaga yang bernaungan pesantren yakni pada lembaga pendidikan yang berada dalam naungan Pondok Pesantren

\footnotetext{
${ }^{11}$ Ibid., hlm. 463.
} 
Tanjung Rejo Situbondo. Secara garis besar, kesimpulan yang saya dapat peroleh dari sini adalah sebagai berikut:

a. Merespon keinginan pelanggan.

Pesantren Tanjung Rejo ini telah banyak Merespon keinginan pelanggan yaitu dengan mengadakan terobosan-terobosan baru. Adapun program-program yang dilakukan adalah 1) program pendidikan, yang mana dengan semakin majunya perkembangan pada zaman saat ini pihak pondok pesantren juga memperbaharui beberapa elemen-elemen yang dapat menunjang terhadap pendidikan yang ada di pondok pesantren, seperti perbaikan terhadap gedung-gedung dan juga pembaharuan terhadap sarana prasarana yang ada. Tidak hanya itu pondok pesantren juga melakukan terobosan-terobosan bagaimana meningkatkan prestasi hasil belajar siswa yang standarisasinya adalah Ujian Nasional (UN), yaitu dengan cara sejak lima bulan sebelum ujian dilaksanakan, diadakan les untuk mata pelajaran yang akan diujikan seperti Matematika, Bahasa Indonesia, dan Bahasa Inggris.

2) program sosial kemasyarakatan, setiap satu bulan sekali pihak dari pondok pesantren pasti mengadakan pengajian di mushollahmushollah atau masjid-masjid yang berada dikalangan masyarakat dengan dipimpin langsung oleh pengasuh pondok pondok pesantren (tidak semua santri bisa mengikutinya hanya santri putra yang terpilih saja yang bisa mengikutinya) kegiatan ini dilakukan karena banyaknya masyarakat yang kurang apresiatif terhadap ajaran agama, selain itu lembaga pondok pesantren juga rutin melakukan baksos (bakti sosial) kepada masyarakat-masyarakat disekitar pondok pesantren setiap dua minggu sekali (seperti membagi-bagikan beras, sayuran, dan bahan sembako lainnya).

Dan tidak lupa pula sebagai bentuk aspirasi pelanggan maka Madrasah membuka kotak saran sebagai media kritik saran dan aspirasi untuk pengembangan madrasah kedepan.

b. Pelayanan terbaik.

Pesantren Tanjung Rejo telah melakukan antisipasi yang diperkirakan mampu mengikuti perkembangan zaman dan tetap 
memberikan pelayanan terbaik bagi para santri-santrinya seperti yang telah tertera dalam pembahasan sebelumnya, misalnya: salah satunya adalah Memperbaharui alat-alat pembelajaran dengan sistem digitalisasi dan juga layanan dalam bidang akademik.

c. Pemberdayaan sumber daya manusia (SDM)

Ada beberapa penunjang untuk peningkatan kualitas guru dan karyawan, diantaranya seperti mengadakan kegiatan training manajemen dan kepemimpinan tenaga pendidik, seminar, dan juga workshop peningkatan kreatifitas mengajar. Pesantren juga mendorong para guru untuk selalu mengikuti perkembangan IPTEK melalui media cetak atau elektronik.

Dalam pondok pesantren ini, Santriwan santriwati juga dituntut untuk tidak hanya cerdas secara intelektual tapi juga cerdas se emosional dan spiritual, seperti memiliki budi pekerti luhur (akhlaqul karimah), serta memiliki keterampilan sebagai bekal masa depan.

\section{KESIMPULAN}

Jadi dapat ditarik kesimpulan bahwa dengan adanya penerapan TQM yang dilakukan dalam lembaga pendidikan yang bernaungan pada pondok pesantren Tanjung Rejo ini, yaitu :

1. Pesantren dapat merespon keinginan pelanggan.

2. Pesantren dapat memberikan pelayanan yang terbaik.

3. Pemberdayaan sumber daya manusia (SDM) yang memuaskan dan memadai. 


\section{DAFTAR RUJUKAN}

Partanto, Pius A. Kamus Ilmiah Populer Surabaya: Arkola. 1994.

Sallis, Edward. Total Quality Management In Education. Terj. Ahmad Ali Riyadi, Cet. Ke-4. Yogyakarta: Ircisod. 2011.

Tjiptono, Fandy dan Anstasia Dian. Total Quality Manajemen. Yogyakarta: Andi. 2001.

Ula, S. Soimatul. Buku Pintar Teori-Teori Manajemen Pendidikan Efektif. Yogyakarta: Berlian. 2013.

Umaedi, Manajemen Peningkatan Mutu, diambil dalam http:// ssep.net /director. html. diakses Pada Tanggal 3 Oktober 2015.

Usman, Husaini. Manajemen Teori, Praktik, Dan Riset Pendidikan. Jakarta: Bumi Aksara. 2006.

Mundiri, A. (2012). PENDIDIKAN TEKNOHUMANISTIK BERBASIS CORE ETHICAL VALUES. At-Tajdid, $1(1), 37-47$.

Mundiri, A. (2015). KOMITMEN ORGANISASIONAL SUMBER DAYA MANUSIA DALAM MENINGKATKAN MUTU PENDIDIKAN PESANTREN. Pedagogik, 3(1), 88-105.

Mundiri, A. (2016). THE LEADERSHIP OF HEADMASTER IN BUILDING A WORK CULTURE BASED ON PESANTREN. In International Conference on Education and Training (pp. 1-7). Malang: Faculty of Education State University of Malang. 